Article

\title{
Influence of External Gaseous Environments on the Electrical Properties of ZnO Nanostructures Obtained by a Hydrothermal Method
}

\author{
Marcin Procek ${ }^{1, *}$, Tadeusz Pustelny ${ }^{1}$ and Agnieszka Stolarczyk ${ }^{2}$ \\ 1 Department of Optoelectronics, Silesian University of Technology, 2 Krzywoustego St., \\ 44-100 Gliwice, Poland; tadeusz.pustelny@polsl.pl \\ 2 Department of Physical Chemistry and Technology of Polymers, Silesian University of Technology, \\ 9 Strzody St., 44-100 Gliwice, Poland; agnieszka.stolarczyk@polsl.pl \\ * Correspondence: marcin.procek@polsl.pl; Tel.: +48-3-2237-1263
}

Academic Editor: Shinya Maenosono

Received: 7 October 2016; Accepted: 18 November 2016; Published: 29 November 2016

\begin{abstract}
This paper deals with experimental investigations of $\mathrm{ZnO}$ nanostructures, consisting of a mixture of nanoparticles and nanowires, obtained by the chemical (hydrothermal) method. The influences of both oxidizing $\left(\mathrm{NO}_{2}\right)$ and reducing gases $\left(\mathrm{H}_{2}, \mathrm{NH}_{3}\right)$, as well as relative humidity $(\mathrm{RH})$ on the physical and chemical properties of $\mathrm{ZnO}$ nanostructures were tested. Carrier gas effect on the structure interaction with gases was also tested; experiments were conducted in air and nitrogen $\left(\mathrm{N}_{2}\right)$ atmospheres. The effect of investigated gases on the resistance of the $\mathrm{ZnO}$ nanostructures was tested over a wide range of concentrations at room temperature (RT) and at $200^{\circ} \mathrm{C}$. The impact of near- ultraviolet (UV) excitation $(\lambda=390 \mathrm{~nm})$ at RT was also studied. These investigations indicated a high response of $\mathrm{ZnO}$ nanostructures to small concentrations of $\mathrm{NO}_{2}$. The structure responses to $1 \mathrm{ppm}$ of $\mathrm{NO}_{2}$ amounted to about: $600 \%$ in $\mathrm{N}_{2} / 230 \%$ in air at $200{ }^{\circ} \mathrm{C}$ (in dark conditions) and $430 \%$ in $\mathrm{N}_{2} / 340 \%$ in air at RT (with UV excitation). The response of the structure to the effect of $\mathrm{NO}_{2}$ at $200{ }^{\circ} \mathrm{C}$ is more than $10^{5}$ times greater than the response to $\mathrm{NH}_{3}$, and more than $10^{6}$ times greater than that to $\mathrm{H}_{2}$ in the relation of $1 \mathrm{ppm}$. Thus the selectivity of the structure for $\mathrm{NO}_{2}$ is very good. What is more, the selectivity to $\mathrm{NO}_{2}$ at RT with UV excitation increases in comparison at elevated temperature. This paper presents a great potential for practical applications of $\mathrm{ZnO}$ nanostructures (including nanoparticles) in resistive $\mathrm{NO}_{2}$ sensors.
\end{abstract}

Keywords: zinc oxide nanostructures; electrical gas sensors; electrical resistivity of $\mathrm{ZnO}$ nanostructures; nitrogen dioxide detection; ultraviolet excitation of semiconductors

\section{Introduction}

Within the group of nanostructured semiconductors with a wide band gap, zinc oxide $(\mathrm{ZnO})$ is a material which has been comprehensively investigated due to its interesting physical and chemical properties and the possibility of its potential extensive application in solar cells, ultraviolet (UV) photodetectors, and light emitters [1-4]. $\mathrm{ZnO}$ is an n-type semiconductor with a band-gap exceeding $3 \mathrm{eV}$. $\mathrm{ZnO}$ crystallizes in three forms: hexagonal (wurtzite), regular (zinc blende), and rarely observed regular (rock-salt) [5]. The wurtzite structure [6,7] is the most stable and the most common form of $\mathrm{ZnO}$ and it is most often used in $\mathrm{ZnO}$ based gas sensors [8]. The wurtzite structure belongs to the spatial group of $\mathrm{C}_{6}^{4}{ }_{6 \mathrm{~V}}$. The tetrahedral system of nodes is typical for covalent binding with sp ${ }^{3}$ hybridization. In the case of $\mathrm{ZnO}$, the binding type has only partly covalent character, with participation of ion bindings [9]. The conduction band of $\mathrm{ZnO}$ is mainly formed by orbitals $4 \mathrm{~s} \mathrm{Zn}^{2+}$, and the valence band forms $2 \mathrm{p} \mathrm{O}^{2-}$. $\mathrm{ZnO}$, like other semiconductor compounds from the II-VI group, has a simple energetic band-gap. 
There are many approaches of synthesis of $\mathrm{ZnO}$ nanostructues described in the literature. Primary synthesis methods include chemical vapor deposition (CVD) [10], metal organic CVD [11], thermal evaporation [12], the template method [13], electrochemical deposition [14], and the laser ablation method [15]. In recent years much interest has been devoted to $\mathrm{ZnO}$ nanostructures obtained by means of chemical methods, mainly participation, sol-gel, and hydrothermal methods [16-25].

Detection and measurement of concentrations of toxic gases such as $\mathrm{NO}_{2}$ or $\mathrm{NH}_{3}$ and explosive gases e.g., $\mathrm{H}_{2}$ have become a necessity due to environmental protection and public safety [26,27]. Also the humidity effect on the gas sensing structures has to be taken into account due to its different values under real operating conditions [28]. Many publications emphasized the potential of ZnO nanostructures in gas sensors $[8,25,27,29,30]$.

$\mathrm{ZnO}$ nanostructures gas sensing properties have been tested both theoretically and experimentally [31-35]. The investigations concerning gas sensors based on $\mathrm{ZnO}$ are already well advanced $[20,29,36]$. Generally, those structures are tested at elevated temperature (from $200{ }^{\circ} \mathrm{C}$ even up to $\left.700{ }^{\circ} \mathrm{C}\right)[18,36]$.

Due to the extended surface of the $\mathrm{ZnO}$ nanostructures it ought to be stressed that their electrical properties depend considerably on the surface phenomena and electrical contact between them. On the surface of $\mathrm{ZnO}$ nanostructures, energy states result from the breaking of chemical bonds and creation of oxygen vacancies. The surface potential $\left(V_{s}\right)$ of the nanostructure determines the curvature of the energy bands on its surface. It follows that between nanostructures the potential barriers, which determine the character of the flow of an electric current, are formed. The classical division of nanostructures distinguishes big grains, where $z_{g}>\lambda_{\mathrm{D}}$ and small grains $z_{g}<\lambda_{\mathrm{D}}$, where $z_{g}$ indicates the size of nanograins and $\lambda_{D}$ is the Debye's shielding radius [31]. The shielding radius $\lambda_{D}$ depends strongly on the concentration of electrons in the bulk $n_{B}$. In the case of $\mathrm{ZnO}$ nanoparticles proceeds: $\lambda_{\mathrm{D}}=1 \mathrm{~nm}$ for $n_{B}=10^{18} \mathrm{~cm}^{-3} ; \lambda_{\mathrm{D}}=3 \mathrm{~nm}$ for $n_{B}=10^{17} \mathrm{~cm}^{-3} ; \lambda_{\mathrm{D}}=10 \mathrm{~nm}$ for $n_{B}=10^{16} \mathrm{~cm}^{-3}$.

The conductivity in structures comprising both large and small grains is a combination of so-called over-barrier and channel conductivities [34]. Theoretical analyses [34,37] indicate that the electric conductivity of a semiconductor nanostructure decreases exponentially with increasing surface potential barriers $\left(\mathrm{e} V_{s}\right)$.

The present paper deals with $\mathrm{ZnO}$ nanostructures obtained by means of the hydrothermal method composed of nanograins and nanowires (small and large grains). The aim of our study was to investigate the electrical properties of such nanostructures in different gaseous and external conditions. The resistance of $\mathrm{ZnO}$ nanostructures affected by various gaseous environments (oxidizing $\mathrm{NO}_{2}$ and reducing gases: $\mathrm{H}_{2}, \mathrm{NH}_{3}$ ) was tested. The effects of carrier gas (nitrogen and air), humidity, temperature, and electromagnetic irradiation to the resistance of the structure were examined. The investigated material showed promising $\mathrm{NO}_{2}$ sensing properties at $\mathrm{RT}$ with ultraviolet excitation and at elevated temperature $\left(200^{\circ} \mathrm{C}\right)$.

With this approach, objective results and conclusions were obtained about the influence of gaseous environments, not only qualitatively, but also quantitatively. Thus, the results of the experimental investigations are of particular importance.

\section{Experimental}

\subsection{Synthesis of $\mathrm{ZnO}$ Nanostructures}

$\mathrm{ZnO}$ nanostructures were obtained by means of the hydrothermal method with ethylenediamine precursor (EDA). The following materials were used: $\mathrm{Zn}\left(\mathrm{NO}_{3}\right)_{2} \cdot 6 \mathrm{H}_{2} \mathrm{O}$, EDA (produced by Simga Aldrich, Saint Louis, MO, USA). NaOH, and ethanol (produced by POCH, Gliwice, Poland).

In a teflon vessel, $0.600 \mathrm{~g} \mathrm{NaOH}$ and $0.440 \mathrm{~g} \mathrm{Zn}\left(\mathrm{NO}_{3}\right)_{2} \cdot 6 \mathrm{H}_{2} \mathrm{O}$ were dissolved in $3 \mathrm{~mL}$ of deionized water. Then $30 \mathrm{~mL}$ ethanol, $5 \mathrm{~mL}$ deionized water, and $5 \mathrm{~mL}$ EDA were added. Under these conditions ZnEDA complex was formed according to the reaction (Equation (1)) [38].

$$
\mathrm{Zn}^{2+}+3 \mathrm{H}_{2} \mathrm{NCH}_{2} \mathrm{CH}_{2} \mathrm{NH}_{2} \leftrightarrow\left[\mathrm{Zn}\left(\mathrm{H}_{2} \mathrm{NCH}_{2} \mathrm{CH}_{2} \mathrm{NH}_{2}\right)_{3}\right]^{2+}
$$


The solution was placed for $30 \mathrm{~min}$ in an ultrasonic bath and then passed to an autoclave. The reaction was run for two hours at a temperature of $180^{\circ} \mathrm{C}$. Above $100^{\circ} \mathrm{C}$ decomposition of ZnEDA complex occurs due to chemical equilibrium shift to the left side of the reaction (Equation (1)) [38]. Elevated temperature causes the hydrolysis of EDA and increases $\mathrm{OH}^{-}$concentration (Equation (2)).

$$
\mathrm{H}_{2} \mathrm{NCH}_{2} \mathrm{CH}_{2} \mathrm{NH}_{2}+2 \mathrm{H}_{2} \mathrm{O} \rightarrow \mathrm{H}_{3} \mathrm{NCH}_{2} \mathrm{CH}_{2} \mathrm{NH}_{2}+2 \mathrm{OH}^{-}
$$

In such a hydrothermal process $\mathrm{Zn}(\mathrm{OH})_{2}$ and next $\mathrm{ZnO}$ were formed according to (Equation (3)).

$$
\mathrm{Zn}^{2+}+\mathrm{OH}^{-} \rightarrow \mathrm{Zn}(\mathrm{OH})_{2} \rightarrow \mathrm{ZnO}
$$

After the reaction in the autoclave, the product was cooled down, the sediment was centrifuged, repeatedly rinsed in deionized water and ethanol. The zinc oxide was dried for $12 \mathrm{~h}$ under reduced pressure (15 mbar) at a RT.

\subsection{Material Characterization Details}

After the syntheses, the $\mathrm{ZnO}$ structures were analyzed by means of a field emission scanning electron microscope (FE-SEM) SUPRA 35 (Carl ZEISS, Jena, Germany).

To explain the molecular nature of the resulting $\mathrm{ZnO}$ nanostructures, they were tested by applying Raman spectroscopy. Raman investigations were made using the Ntegra Spectra system (NT-MDT, Moscow, Russia), a microscope equipped with a CCD (Charge Coupled Device) detector using green (532 $\mathrm{nm}$ ) laser excitation.

To determine the crystal nature of the $\mathrm{ZnO}$ nanostructures, $\mathrm{X}$-ray powder diffraction (XRD) measurements were made. XRD was investigated using a diffractometer X'Pert Pro MPD (PANAlytical, Almelo, Netherlands), containing a cobalt lamp with the main wavelength of $0.179 \mathrm{~nm}$ (K-alpha line) in its spectrum.

For the inspection of the grains' distribution on the transducer a scanning electron microscope (SEM) Inspect S50 (FEI, Hillsboro, OR, USA) was used.

\subsection{Fabrication of Resistive Structures Based on $\mathrm{ZnO}$ Nanostructures}

In order to investigate the electrical properties of $\mathrm{ZnO}$ nanostructures, a resistive structure on an interdigital transducer (IDT) was made. ZnO nanostructures were deposited on an IDT by means of a drop coating method. The transducer was obtained using the photolithography method, from a $300 \mathrm{~nm}$ thick gold layer on a silicon substrate with a $1 \mu \mathrm{m} \mathrm{SiO}$ layer. The width of the electrodes (including the distance from each other) was $5 \mu \mathrm{m}$. The dimensions of the transducer were $10 \times 10 \mathrm{~mm}$. For the purpose of depositing $\mathrm{ZnO}$ nanostructures on the substrate, they were dispersed in pure hexane (produced by POCH, Gliwice, Poland) by means of an ultrasonic bath (the mixing lasted 5 min). Next the suspension was dropped onto the transducer and dried at RT. The material not adhering to the substrate was removed using compressed air with a pressure of 10 bar. Prior to the measurements, the structure was heated up to a temperature of $200{ }^{\circ} \mathrm{C}$ to remove the retained dispergent and to let the structure dry.

Three such sensing structures were fabricated and tested, all of them gave similar results and had similar properties. In order to compare the reaction of the $\mathrm{ZnO}$ nanostructures affected by external atmospheres, temperature and light excitation the results for the same structure are presented in the text.

\subsection{Gas Measurement Details}

$\mathrm{ZnO}$ nanostructures were investigated in various gaseous atmospheres and under various environmental conditions (at different temperature and UV lighting). This required a special measuring chamber, in which the transducer with the deposited $\mathrm{ZnO}$ nanostructures was placed (Figure 1b). This 
measuring chamber can heat the structure by means of a thick-layer heater on an $\mathrm{Al}_{2} \mathrm{O}_{3}$ substrate and can measure the temperature by a Pt-100 sensor. A quartz window and an ultraviolet $\operatorname{LED}(\lambda \approx 390 \mathrm{~nm})$ permits the illumination of the sample by means of UV radiation. The transducer mounted on the heater was mobilized on a special chip, and the contacts between its leg and the transducer electrodes were constructed by means of wire bonding (gold wire with a diameter of $25 \mu \mathrm{m}$ ) using the bonder 53XX-BDA (made by F\&K DELVOTEC, Braunau, Austria). The cover of this chamber consists of PTFE and is equipped with fast gas connectors of stainless steel. The block scheme of the measurement setup is shown in Figure 1a. The acquisition of data and control of the measurements were accomplished by a PC. The temperature was controlled and measured by the PID controller SR94 (produced by Shimaden, Tokyo, Japan). In all these cases, the resistance was measured making use of a multichannel switch unit 34970A (produced by AGILENT, Santa Clara, CA, USA).
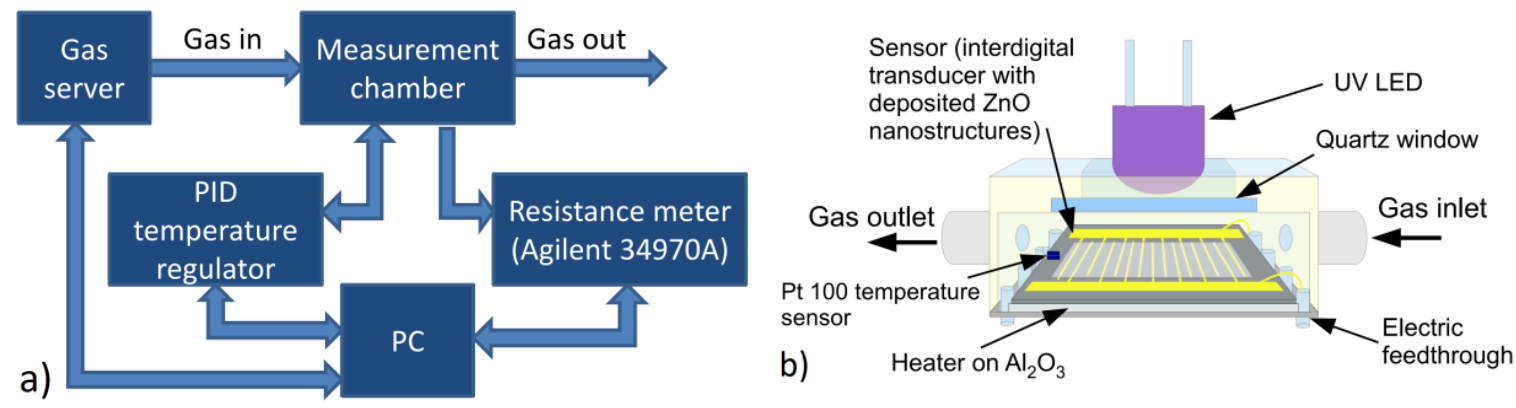

Figure 1. Scheme of (a) the measurement stand and (b) the measurement chamber.

The applied gaseous mixtures were produced by a gas server allowing precise preparation of the gaseous atmospheres, composed of any kind of carrier gas and up to five different gases of precisely determined concentrations. The gas server was described in an earlier paper [39].

The flow of gas through the measuring chamber was constant for all the measurements $(500 \mathrm{~mL} / \mathrm{min})$. During the measurements two different gases were applied as the atmosphere (carrier gases), viz. nitrogen 6.0 and synthetic air $\left(\mathrm{O}_{2}: 20 \% ; \mathrm{N}_{2}: 80 \%\right)$. Their relative humidity was the same, amounting to about: $6 \% \pm 1 \%\left(\right.$ at $22{ }^{\circ} \mathrm{C}$ ). In the experiments, adequate standard gases were used, viz. $\mathrm{H}_{2}$ : $99.9994 \% ; \mathrm{NO}_{2}: 100 \mathrm{ppm}$ in $\mathrm{N}_{2} ; \mathrm{NH}_{3}: 500$ ppm in air. The humidity of the gas was changed by means of a bubble humidifier and monitored by an RH meter. The measurement of the response of the $\mathrm{ZnO}$ nanostructures to the effect of the gases consisted in alternating the introduction of pure carrier gas into the measuring chamber and the tested gas with the given concentration in the atmosphere (synthetic air or nitrogen $\mathrm{N}_{2}$ ). In each successive cycle, the concentration of the gas was raised. The measurements were performed at $\mathrm{RT}=23{ }^{\circ} \mathrm{C}$, at elevated temperature of $\mathrm{T}=200{ }^{\circ} \mathrm{C}$ and also when illuminating the sample of $\mathrm{ZnO}$ nanostructure by UV light at RT.

The structure responses to a given gases were calculated according to the formula:

$$
\text { Response }=\frac{R_{g}-R_{a}}{R_{a}} \cdot 100 \%,
$$

where $R_{a}$ is the sensor resistance in the carrier gas and $R_{g}$ is the sensor resistance after the action with the selected gas.

\subsection{Details Concerning Spectral Measurements}

The dependence of the resistance of $\mathrm{ZnO}$ nanostructures on the wavelength of optical excitation was measured. The resistance of the $\mathrm{ZnO}$ nanostructures was measured during illumination with light in the range from $300 \mathrm{~nm}$ to $750 \mathrm{~nm}$. The source of light was a xenon lamp, and the wavelength was measured by tuning the monochromator DH-10 (made by Jobin Yvon, Lonjumeau, France). In this case, the measurements were performed in atmospheric air, at RT. The intensity of light was kept at 
a constant level and monitored by a spectrometer HR 2000 + ES (made by Ocean Optics, Dunedin, FL, USA).

\subsection{Details Concerning the Temperature Measurements}

Investigations of the dependence of the resistance of $\mathrm{ZnO}$ nanostructures on temperature $R(T)$ in various gaseous atmospheres, viz. synthetic air and nitrogen, were performed. In each series of tests, the sample was prepared by heating in a given carrier gas up to $300{ }^{\circ} \mathrm{C}$ and then cooling down to RT. The resistance was recorded for other temperature cycles of heating and cooling in the given atmosphere. The temperature was changed within the range of $40-300{ }^{\circ} \mathrm{C}$ every $10{ }^{\circ} \mathrm{C}$ until the resistance became stable (the interval of time was equal to about $\Delta t=2 \mathrm{~min}$ ).

\section{Results and Discussion}

\subsection{ZnO Structures Characterization}

Morphology of the $\mathrm{ZnO}$ structures is presented on FE-SEM images in Figure 2. The nanostructures of $\mathrm{ZnO}$ obtained by the hydrothermal method constitute a rich mixture of different geometrical forms, from nanobars and nanotubes, most with lengths up to a few $\mu \mathrm{m}$ up to nanoparticles such as nanolumps with sizes of a few nm. From the physical point of view, a division of nanostructures into the so-called large and small ones is reasonable [31]. In our case, the large geometrical variety of $\mathrm{ZnO}$ nanostructures and the wide range of their sizes require them to be treated as a mixture of both large and small nanostructures.

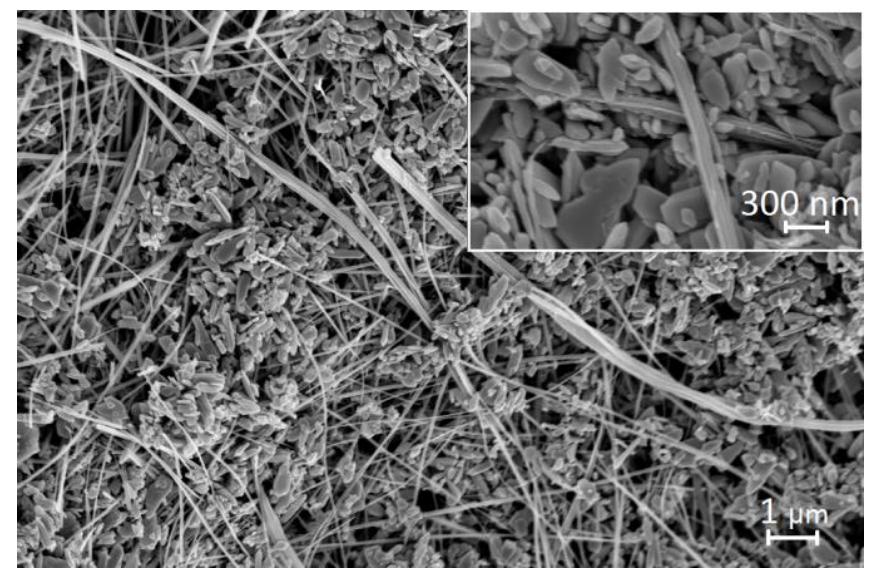

Figure 2. Field emission scanning electron microscope (FE-SEM) image of the $\mathrm{ZnO}$ nanostructures (magnification $20,000 \times$ and $50,000 \times$ ).

The XRD results are shown in Figure 3. The obtained diffractogram is characteristic for the hexagonal structure of $\mathrm{ZnO}$ with the spatial group P63mc (patterns are consistent with the ICSD card at the code No. 180052 titled "Zinc Oxide-Nanoparticles"). In the spectrum, no additional peaks could be detected. The average crystal sizes estimated from XRD patterns using the Scherer equation [40] are in the range of $227 \mathrm{~nm}$ (for crystallographic plane (100)) to $3 \mathrm{~nm}$ (for plane (203)). The obtained results confirm conclusions from FE-SEM where mixtures of structures with different shapes were observed.

Figure 4 presents the Raman spectrum of $\mathrm{ZnO}$ nanostructures. The obtained spectrogram is compatible with Raman peak values for $\mathrm{ZnO}$ nanocrystals given in the reference [6] with slight drift (in the range of $2-5 \mathrm{~cm}^{-1}$ ) caused by different crystals sizes. In this case all the atoms occupy $C_{3 \mathrm{v}}$ sites. Group theory shows that active Raman modes are A1+E1+2E2. The phonons of A1 and E1 symmetry are polar phonons and, hence, exhibit different frequencies for the transverse-optical (TO) and longitudinal-optical (LO) phonons [6]. Raman modes at 332, 380, 438, 540 and $579 \mathrm{~cm}^{-1} \mathrm{are}^{-}$ denoted as 2E2, E1(TO), E2, A1(LO) and E1(LO) modes, respectively. 


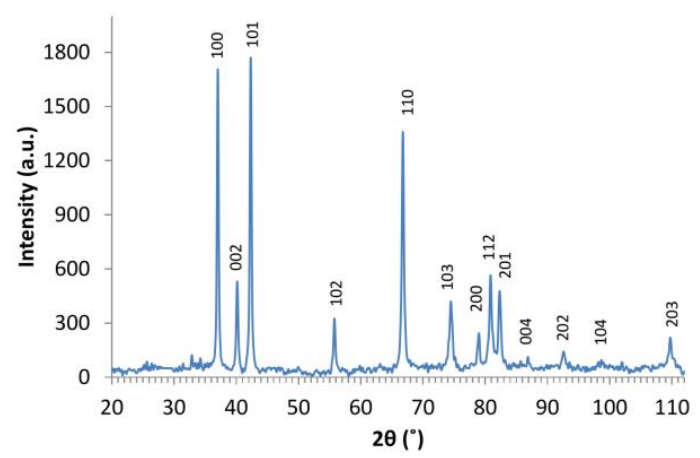

Figure 3. X-ray powder diffraction (XRD) patterns of $\mathrm{ZnO}$ nanostructures $(\lambda=0.179 \mathrm{~nm})$.

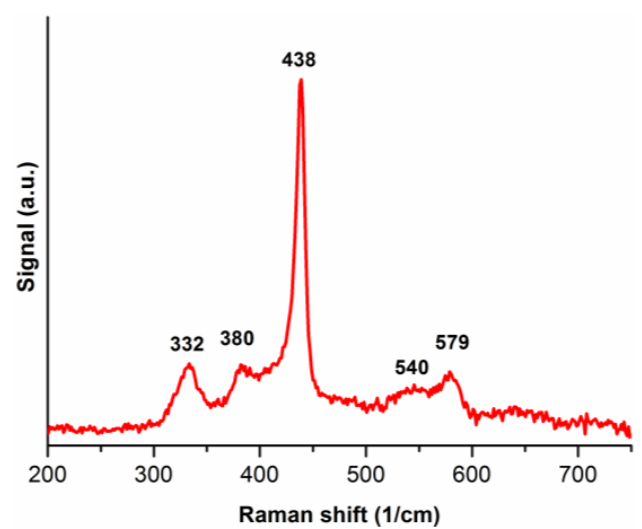

Figure 4. Raman spectrum of $\mathrm{ZnO}$ nanostructures.

$\mathrm{ZnO}$ nanostructures deposited on the IDT have a relatively uniform distribution and good adhesion to the substrate, as may be observed on the SEM image in Figure 5. The adhesion of the nanostructures to the transducer is the result of van der Waals and electrostatic forces. Thus, small grains which have smaller mass to contact area ratio have better adhesion than bigger ones. Long nanowires which have contact to a few electrodes stabilized the electrical properties of the sensor structure. Thanks to the mixture of small grains and nanowires, layers with good adhesion and electrical stability were obtained. The thickness of the layer is not uniform and its value is in the range from single crystalline size up to single micrometers (Figure 5).

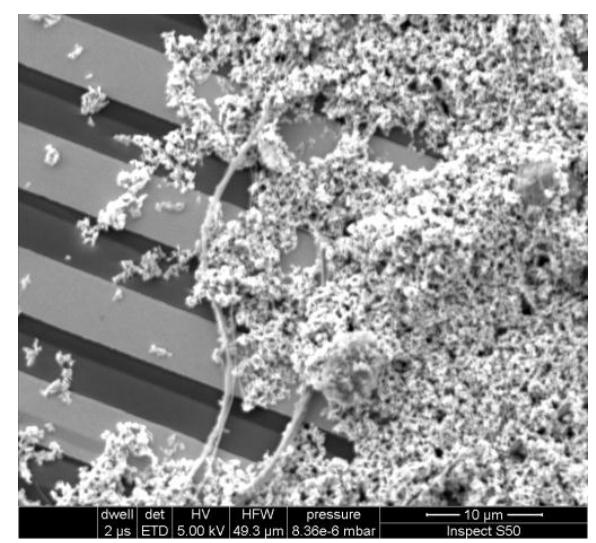

Figure 5. Scanning electron microscope (SEM) image of the distribution of $\mathrm{ZnO}$ nanostructures on the interdigital transducer. 


\subsection{Investigations of the Influence of Light on the Resistance of $\mathrm{ZnO}$ Nanostructures}

The results of spectral tests $R(\lambda)$ are gathered in Figure 6. Changes of the resistance are observed in the range between 300 and $500 \mathrm{~nm}$. Below $380 \mathrm{~nm}$ the resistance changes are smaller. The characteristics show the existence of an absorption edge in the $\mathrm{ZnO}$ nanostructures somewhere about $380 \mathrm{~nm}$. In crystalline $\mathrm{ZnO}$ the absorption edge (corresponding to the band gap) is also observed at about $380 \mathrm{~nm}[9]$, which corresponds to an energy $\Delta E$ of $3.25 \mathrm{eV}$.

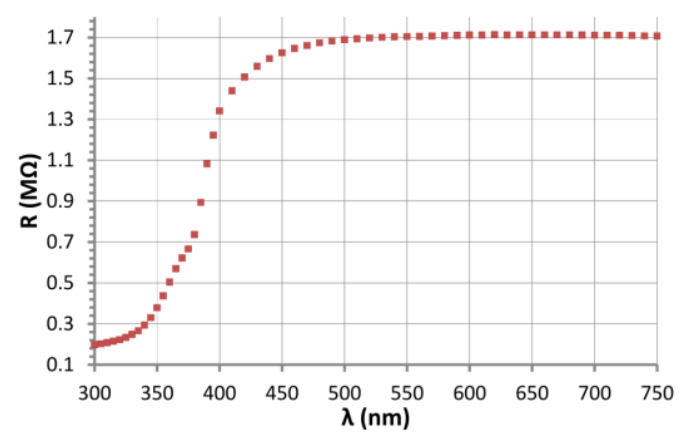

Figure 6. The dependence of the resistance of $\mathrm{ZnO}$ nanostructures on the wavelength.

The decrease of the resistance under UV irradiation is mainly caused by the increase in the concentration of the electrical charges (electrons and holes), as a result of photogeneration as well as excitation of electrons from the surface states. Of no less importance is the phenomenon of photocatalysis leading to the desorption of the gases (especially oxygen) absorbed (in the form of molecules, atoms, and ions) on the surface active centers of the $\mathrm{ZnO}$ nanostructures [41].

\subsection{The Effect of the Carrier Gas and Temperature on the Electrical Properties of ZnO Nanostructures}

The authors attempted to explain experimentally to what extent the oxygen contained in the air affects the interaction of the tested gases with $\mathrm{ZnO}$ nanostructures. Figure 7 illustrates the dependence of the electrical resistance on the temperature of the layer of $\mathrm{ZnO}$ nanostructures in atmospheres of synthetic air and in nitrogen.

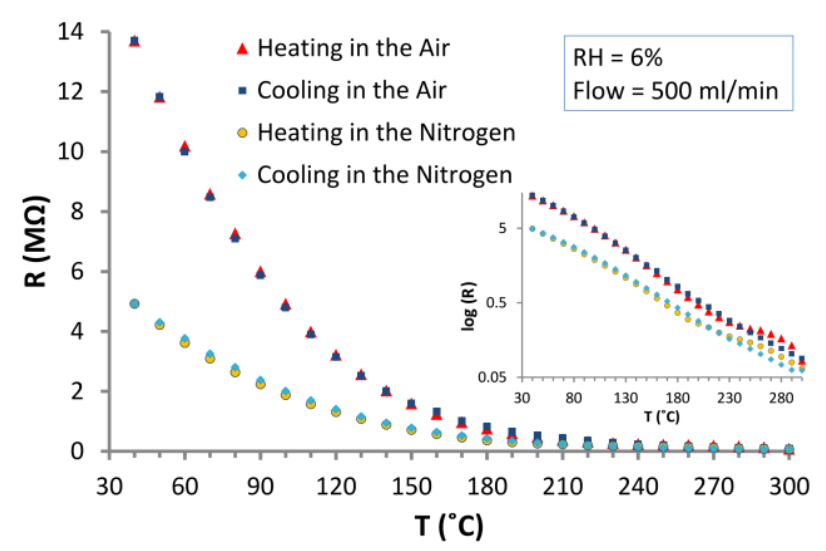

Figure 7. Dependence of the resistance of the structure based on $\mathrm{ZnO}$ nanoparticles on temperature in: synthetic air and in nitrogen (gas flow $=500 \mathrm{~mL} / \mathrm{min} ., \mathrm{RH}=6 \%$ ).

The diagram of $R(T)$ (Figure 7) shows the differences between the resistance values in both carrier gases during cooling and heating the sample. It is particularly noticeable in the temperature range from $40-180^{\circ} \mathrm{C}$. It can be seen in Figure 7 that at the measured temperature range the resistance of $\mathrm{ZnO}$ nanostructures is higher in air (in the presence of oxygen) than that in nitrogen. An increase 
in the temperature reduces the resistance of the nanostructures. It is the effect of a decrease of the concentration of electrons in the surface states and the reduction of the surface potential barriers of $\mathrm{ZnO}$ nanostructures. In the nitrogen atmosphere the created oxygen vacancies stay unoccupied.

\subsection{The Reaction of $\mathrm{ZnO}$ Nanostructures to $\mathrm{NO}_{2}$}

As an example of oxidizing gas small concentrations of $\mathrm{NO}_{2}(1-20 \mathrm{ppm})$ were chosen.

The characteristics shown in Figure 8a prove that at $\mathrm{RT} \mathrm{ZnO}$ nanostructures reacted to $\mathrm{NO}_{2}$ only in the first cycle (1 ppm) where their resistance increased by c.a. $50 \%$ in $\mathrm{N}_{2}$ and $30 \%$ in air. When the resistive $\mathrm{ZnO}$ structure was "saturated" its further exposure to $\mathrm{NO}_{2}$ action at $\mathrm{RT}$ did not result in a change of the resistance. At RT, when $\mathrm{NO}_{2}$ was removed from the carrier gas, the structures did not recover, and the resistance of the structure did not return to its initial values. The results at $200{ }^{\circ} \mathrm{C}$ are presented in Figure $8 \mathrm{~b}$. Heating the structure up to $200^{\circ} \mathrm{C}$ resulted in a strong increase of the response of $\mathrm{ZnO}$ nanostructures to $\mathrm{NO}_{2}$. In this case responses to $1 \mathrm{ppm}$ of $\mathrm{NO}_{2}$ were c.a. $600 \%$ in nitrogen and c.a. $230 \%$ in air. At the elevated temperature, sensor recovery is observed (Figure $8 \mathrm{~b}$ ), which is caused by the desorption of $\mathrm{NO}_{2}$ from the $\mathrm{ZnO}$ nanostructures. It is revealed by the decrease in the resistance after each $\mathrm{NO}_{2}$ exposure.
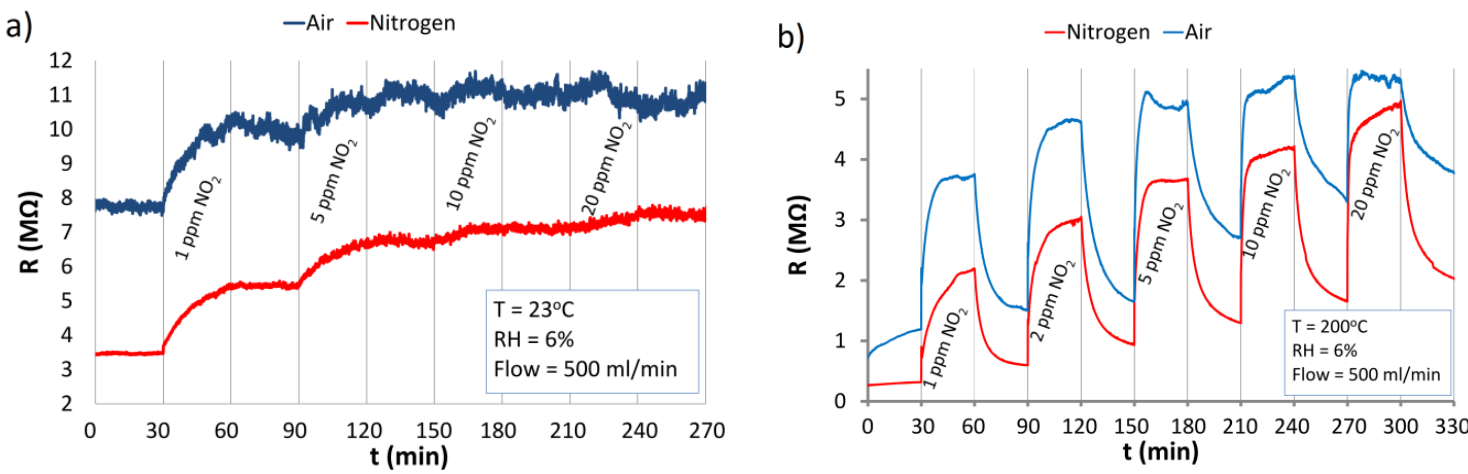

Figure 8. The reaction of $\mathrm{ZnO}$ nanostructures to $\mathrm{NO}_{2}$ in the atmospheres of synthetic air and nitrogen at: (a) RT; (b) elevated temperature of $200^{\circ} \mathrm{C}$.

The elevated temperature $\left(200^{\circ} \mathrm{C}\right)$ of the structure leads to an increase in free chemical bonds (oxygen vacancies) on the surface of $\mathrm{ZnO}$ nanostructures, which can bind with gas molecules. The changes of the resistance of the structures depend also on the concentration of electrons, which are thermally transferred from traps localized in the band-gap to the conduction band. Therefore, the spatial distribution of electrical charges in the $\mathrm{ZnO}$ nanostructures is also changed. The temperature of about $200{ }^{\circ} \mathrm{C}$ also facilitates desorption of the $\mathrm{NO}_{2}$ from the active centers. The investigations showed that detoxication after $1 \mathrm{ppm}$ of $\mathrm{NO}_{2}$ exposure of the structure requires a longer time in an atmosphere of synthetic air $\left(t_{90 \%}=880 \mathrm{~s}\right)$ than in nitrogen $\left(t_{90 \%}=700 \mathrm{~s}\right)$. In an atmosphere of air, active centers can join to both $\mathrm{NO}_{2}$ and oxygen simultaneously [34,42,43].

The differences between the structure reaction to $\mathrm{NO}_{2}$ at $\mathrm{RT}$ and elevated temperature can be explained by a chemical mechanism of this interactions. At $\mathrm{RT}, \mathrm{NO}_{2}$ is absorbed by $\mathrm{ZnO}$ nanostructures mainly in the form of $\mathrm{NO}_{3}{ }^{-}$ions with evacuation of gaseous $\mathrm{NO}[8,44]$. At the elevated temperature, the absorbed $\mathrm{NO}_{3}{ }^{-}$undergoes decomposition to gaseous $\mathrm{NO}_{2}$ and adsorbed $\mathrm{O}^{-}$. As $\mathrm{NO}_{2}$ and its derivatives are oxidizing gases, they incorporate electrons from the $\mathrm{ZnO}$ nanostructures, which increase their resistance.

The results of the response of $\mathrm{ZnO}$ nanostructures to $\mathrm{NO}_{2}$ in air and nitrogen atmospheres under UV illumination and at RT are shown in Figure 9. Resistance of the structure increases proportionally to $\mathrm{NO}_{2}$ concentration. The structure responses to $1 \mathrm{ppm}$ of $\mathrm{NO}_{2}$ amount to $430 \%$ in $\mathrm{N}_{2}$ and $340 \%$ in the air. Under this conditions in both carrier gases structure recovery occurs, which proves that UV illumination allows a desorption of $\mathrm{NO}_{2}$ from the $\mathrm{ZnO}$ nanostructures at RT. 


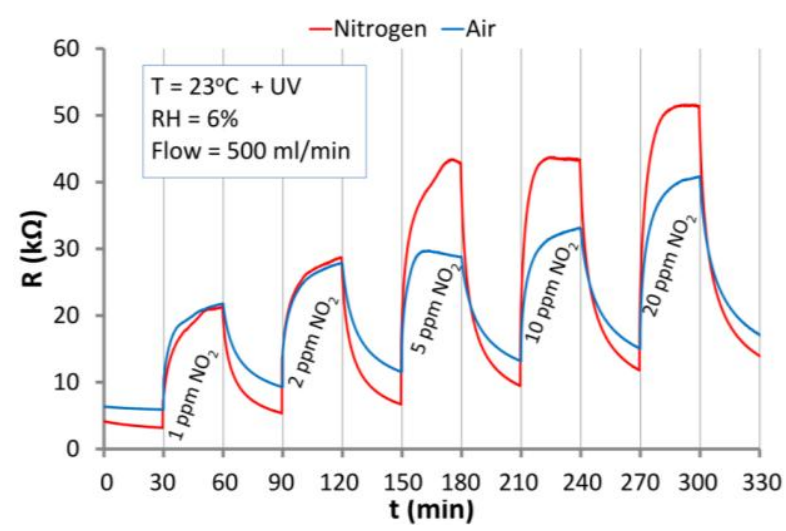

Figure 9. The response of the $\mathrm{ZnO}$ nanostructures to the effect of $\mathrm{NO}_{2}$ and ultraviolet (UV) irradiation in atmospheres of air and nitrogen at RT.

The excitation of $\mathrm{ZnO}$ nanostructures by means of $\mathrm{UV}$ radiation causes both photogeneration of electron-hole pairs, and generation of charge carriers from the surface states. On the $\mathrm{ZnO}$ surface the photocatalytic reactions of the adsorption (with capture of electron) and desorption (with capture of hole) of oxygen can occur [45].

In the case of air conditions both reactions occur and the surface potential is the result of equilibrium between them. In nitrogen only oxygen desorption occurs, and thus the surface potential is smaller than in air. This can be observed in the differences of base resistances under both conditions (Figure 9). This phenomenon has also impact on the kinetics of the reaction of the structure with $\mathrm{NO}_{2}$. Due to the higher oxygen vacancy concentration in nitrogen the structure response is higher than under air conditions.

The presented results prove that UV excitation enables $\mathrm{ZnO}$ nanostructures to respond and recover at RT. Under air conditions the structure response is higher at RT with UV activation than at elevated temperature. This makes UV excited $\mathrm{ZnO}$ nanostructures promising materials for low concentration $\mathrm{NO}_{2}$ sensors operating at RT.

\subsection{Reactions of $\mathrm{ZnO}$ Nanostructures with Reducing Gases}

\subsubsection{The Reaction of $\mathrm{ZnO}$ Nanstructures with Hydrogen}

The reaction of $\mathrm{ZnO}$ nanostructures with $\mathrm{H}_{2}$ in an atmosphere of synthetic air and nitrogen at RT and at $200{ }^{\circ} \mathrm{C}$ is presented in Figure 10 . The structure was exposed to relatively high concentrations of hydrogen in the range of a few percent $\left(1 \% \equiv 10^{4} \mathrm{ppm}\right)$. The detection of such high $\mathrm{H}_{2}$ concentrations is important because hydrogen is explosive at $4 \%$ concentration in air.
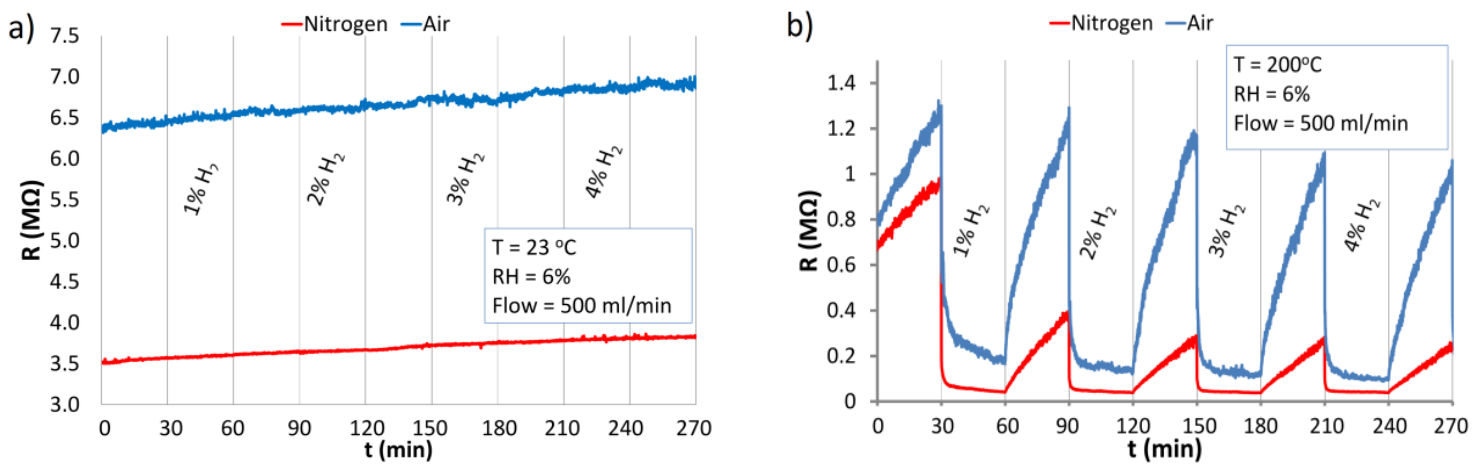

Figure 10. Reaction of the $\mathrm{ZnO}$ nanostructures with $\mathrm{H}_{2}$ in the atmosphere of synthetic air and nitrogen at: (a) RT; (b) temperature of $200{ }^{\circ} \mathrm{C}$. 
At RT (Figure 10a) no reaction of the $\mathrm{ZnO}$ nanostructures to $\mathrm{H}_{2}$ was observed. Contrary to RT, at elevated temperature $\left(200^{\circ} \mathrm{C}\right)$ under both atmospheres (Figure $\left.10 \mathrm{~b}\right)$ a relatively high and fast response to hydrogen was observed. The response is characteristic of reducing gases, which decrease the resistance of $\mathrm{n}$-type semiconductors. In comparison to adsorption, the rate of desorption at $200{ }^{\circ} \mathrm{C}$ is rather slow, especially under nitrogen atmosphere. Due to the relatively high concentrations of $\mathrm{H}_{2}$, there are very small differences between the responses to various concentrations. A temperature of $200{ }^{\circ} \mathrm{C}$ seems to be high enough for reversible adsorption of dissociatively chemisorbed hydrogen to occur. Adsorption of $\mathrm{H}_{2}$ results in the formation of a $\mathrm{H}-\mathrm{O}-\mathrm{ZnO}$ surface [46]. The response of $\mathrm{ZnO}$ nanostructure at $200{ }^{\circ} \mathrm{C}$ is relatively fast because of the high concentration of $\mathrm{H}_{2}$ and the small size of hydrogen molecules. The hydrogen ions react with oxygen ions on the $\mathrm{ZnO}$ surfaces and may cause desorption of oxygen from active centers and the $\mathrm{ZnO}$ lattice [25,29]. This results in a decrease in the potential barriers between nanograins and thus the resistance of the sensor structure is reduced. The desorption process is faster in air than in nitrogen (Figure 10b). The oxygen from the air leads to a re-oxidation of the oxide vacancies on the surface of $\mathrm{ZnO}$ nanostructures during recovery of the structure. In the nitrogen atmosphere, the resistive structure recovers very weakly due to the absence of oxygen (or other oxidizing analytes) which can fill the vacancies created by hydrogen. Therefore the role of oxygen from the air is important in the sensor recovery process.

The reaction of $\mathrm{ZnO}$ nanostructures to $\mathrm{H}_{2}$ under continuous $\mathrm{UV}$ irradiation at $\mathrm{RT}$ is presented in Figure 11. Similar to dark conditions (Figure 10a), the resistive structure practically does not react to hydrogen at RT. Under UV radiation in both carrier gases, only small changes of resistance were observed directly after letting $\mathrm{H}_{2}$ into the chamber (Figure 11). This could be the effect of the change in oxygen concentration or $\mathrm{RH}$ after mixing $\mathrm{H}_{2}$ with the carrier gas. Hydrogen also has a very high heat conductivity, and at such high concentration can cause small local changes in the temperature of the $\mathrm{ZnO}$ resistive structure.

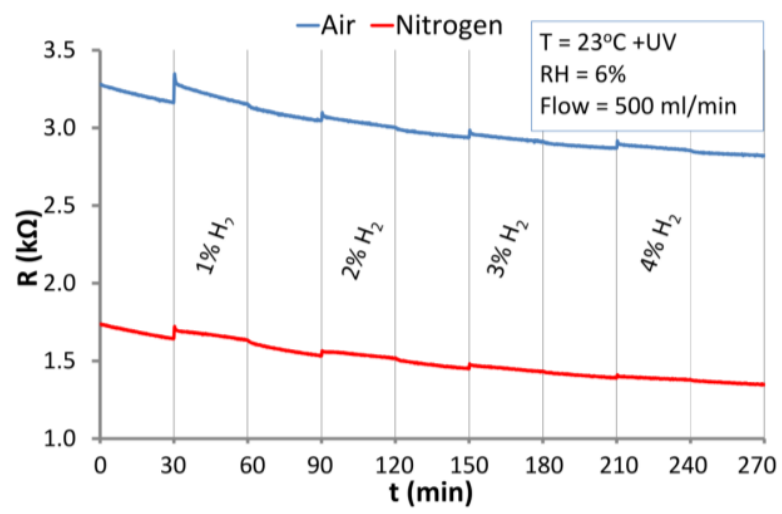

Figure 11. Response of the $\mathrm{ZnO}$ nanostructures to $\mathrm{H}_{2}$ and at $\mathrm{UV}$ irradiation under atmospheres of air and nitrogen at RT.

Due to the fact that the concentrations of hydrogen in the atmosphere of air were high, the saturation of the structure by hydrogen $\left(\mathrm{H}_{2}, \mathrm{H}^{+}\right)$is evident in the diagram in Figure $10 \mathrm{~b}$. The reaction of the $\mathrm{ZnO}$ nanostructure with $1 \%$ and $4 \%$ hydrogen is similar. At $\mathrm{RT}$, the structure is not sensitive to the presence of hydrogen, even after optical excitation (Figure 11). The $\mathrm{H}_{2}$ molecules are not very reactive under standard conditions (the orbital s of the $\mathrm{H}_{2}$ molecule is complete).

\subsubsection{The Reaction of $\mathrm{ZnO}$ Nanostructures with Ammonia}

The results of the investigations of the reaction of the structure to $\mathrm{NH}_{3}$ are shown in Figure 12. At $\mathrm{RT}, \mathrm{NH}_{3}$ reacts with the $\mathrm{ZnO}$ nanostructures only slightly, decreasing the resistance of the $\mathrm{ZnO}$ structure (Figure 12a). In both atmospheres at RT, the reaction of $\mathrm{ZnO}$ nanostructures with ammonia 
is negligible and desorption is practically undetectable. At elevated temperature $\left(20{ }^{\circ} \mathrm{C}\right)$, the $\mathrm{ZnO}$ nanostructures react distinctly with $\mathrm{NH}_{3}$ under both atmospheres (Figure 12b).
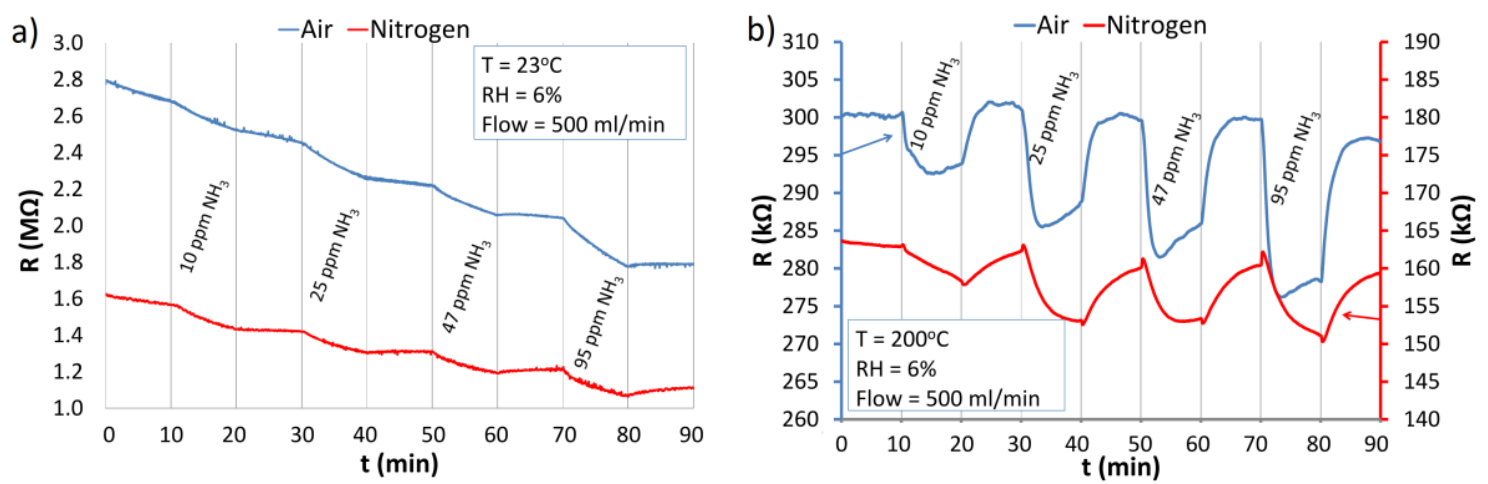

Figure 12. Reactions of the $\mathrm{ZnO}$ nanostructures with $\mathrm{NH}_{3}$ in air and nitrogen atmospheres at: (a) RT; (b) $200{ }^{\circ} \mathrm{C}$.

Similar to the case of $\mathrm{H}_{2}$, the interactions of $\mathrm{ZnO}$ nanostructures with $\mathrm{NH}_{3}$ were typical for reducing gases (resistance decreases). At the elevated temperature, a relatively fast desorption took place in the atmosphere of air and a comparably slow one in the nitrogen atmosphere. Figure 13 presents the sensitivity of the optically excited (UV) ZnO nanostructures exposed to ammonia in air and nitrogen atmospheres at RT.

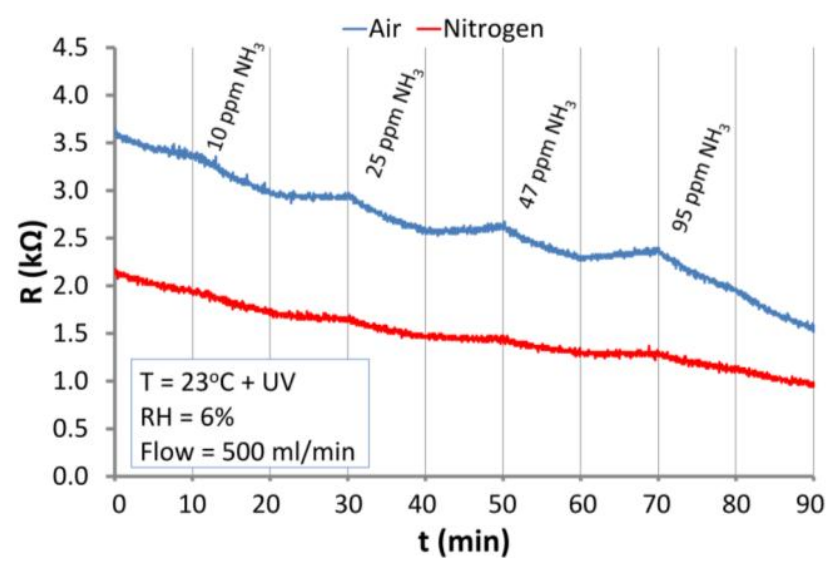

Figure 13. The response of the $\mathrm{ZnO}$ nanostructures to $\mathrm{NH}_{3}$ under continuous UV irradiation under atmospheres of air and nitrogen at $\mathrm{RT}\left(23^{\circ} \mathrm{C}\right)$.

It ought to be stressed that in spite of the similar character of the behavior of $\mathrm{ZnO}$ nanostructures exposed to $\mathrm{NH}_{3}$ and $\mathrm{H}_{2}$, the range of changes differs, taking into account the many times smaller concentrations of ammonia.

\subsection{The Response of $\mathrm{ZnO}$ Nanostructures to Changes of the Humidity}

Figure 14 presents the reaction of $\mathrm{ZnO}$ nanostructures to changes of the $\mathrm{RH}$ level under atmospheres of air and nitrogen. The tests were performed at RT $\left(23^{\circ} \mathrm{C}\right)$ and elevated temperature of $200^{\circ} \mathrm{C}$. 

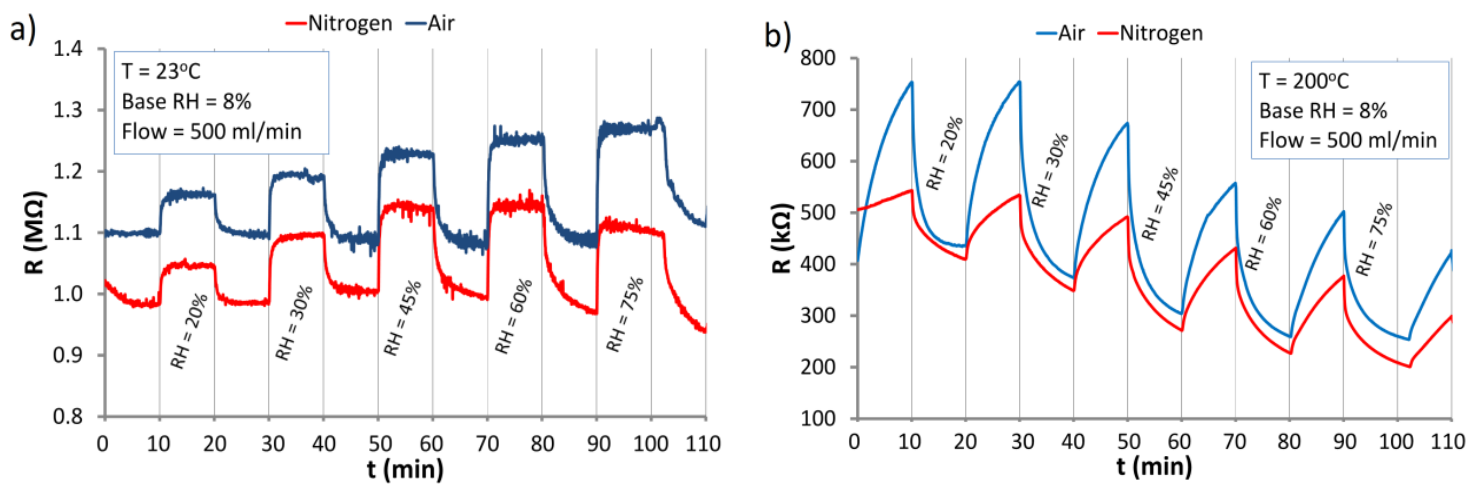

Figure 14. Reaction of the $\mathrm{ZnO}$ nanostructures to changes of the relative humidity (RH) level under atmospheres of nitrogen and air at: (a) RT; (b) $200{ }^{\circ} \mathrm{C}$.

The investigations (Figure 14) proved that the $\mathrm{ZnO}$ nanostructures are sensitive to humidity even at RT. It ought to be stressed that their response to RH reveals a different direction of resistance change, depending on the temperature at which the measurements were taken. At RT water is physically absorbed by $\mathrm{ZnO}$ nanostructures due the dipole character of the water molecules. The water molecules are absorbed by $\mathrm{ZnO}$ nanostructures as a result of van der Waals forces as well as, in some steps, by electrostatic forces. The polarity of $\mathrm{H}_{2} \mathrm{O}$ molecules changes the distribution of the electrical charges on the surface of $\mathrm{ZnO}$ nanostructures, therefore the resistance increases with increase in $\mathrm{RH}$. This indicates that at low temperatures no dissociative adsorption of $\mathrm{H}_{2} \mathrm{O}$ molecules on $\mathrm{ZnO}$ surface takes place. The $\mathrm{H}_{2} \mathrm{O}$ dissociation can be observed at elevated temperatures from about $150{ }^{\circ} \mathrm{C}$ upwards [32]. This is connected with the supply of electrical charges to $\mathrm{ZnO}$ nanostructures and the neutralization of some part of the adsorbed oxygen molecules and lattice oxygen (caused by the reaction of $\mathrm{H}^{+}$ with $\mathrm{O}^{-}$). This leads to increasing the concentration of charge carriers. As an effect of this increase, the resistance of the structure drops, as can be seen in Figure $14 \mathrm{~b}$. At the temperature of about $200{ }^{\circ} \mathrm{C}$, the effect of the dissociation of water on the electrical properties of $\mathrm{ZnO}$ nanostructures dominates. The investigations showed that at the temperature exceeding $200^{\circ} \mathrm{C}$ humidity is chemisorbed (hydroxyl groups are joined to the $\mathrm{ZnO}$ nanostructures [31]).

Under UV irradiation at RT (Figure 15), the sensor reacts similarly to the dark conditions at RT (Figure 15a). An increase in the $\mathrm{RH}$ level indicates the increase in the resistance of $\mathrm{ZnO}$ nanostructures. That proves that UV radiation does not cause dissociative chemisorption of water. As in the case of dark conditions under UV irradiation physical adsorption occurs. In the atmosphere of nitrogen, the structure reacts to RH changes weaker than in the atmosphere of air. This can be explained by the lower concentration of negatively charged oxygen adsorbed on the surface in the presence of nitrogen.

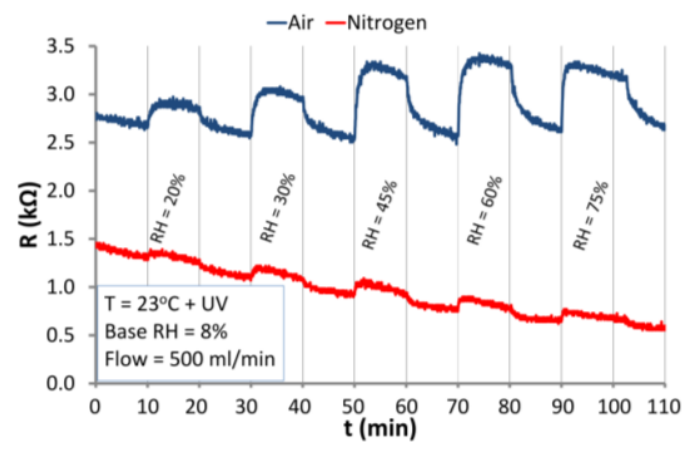

Figure 15. Responses of the $\mathrm{ZnO}$ nanostructures to $\mathrm{RH}$ changes under UV irradiation under atmospheres of air and nitrogen at $\mathrm{RT}\left(23^{\circ} \mathrm{C}\right)$. 


\section{Summary and Conclusions}

The aim of our study was to investigate the electrical properties of $\mathrm{ZnO}$ nanostructures obtained by the hydrothermal method composed of nanograins and nanowires (small and large grains) in different gaseous and external conditions. The effects of different gases, carrier gas (nitrogen and air), humidity, temperature, and electromagnetic irradiation on the resistance of the structure was examined. The investigated material showed promising $\mathrm{NO}_{2}$ sensing properties at $\mathrm{RT}$ with ultraviolet excitation and at elevated temperature $\left(200^{\circ} \mathrm{C}\right)$.

Our studies showed the role of atmospheric oxygen with respect to the sensitivity of the structure based on $\mathrm{ZnO}$ nanostructures on the effect of oxidizing and reducing gases. The experimental studies showed that the presence of oxygen in the gaseous atmosphere affects the electrical properties of the structure. The research showed that the sensitivity of $\mathrm{ZnO}$ nanostructures to gases depends on the temperature of these structures and their optical excitation (UV radiation).

The structure responses (Equation (1)) to all the investigated gases are summarized in Figure 16.

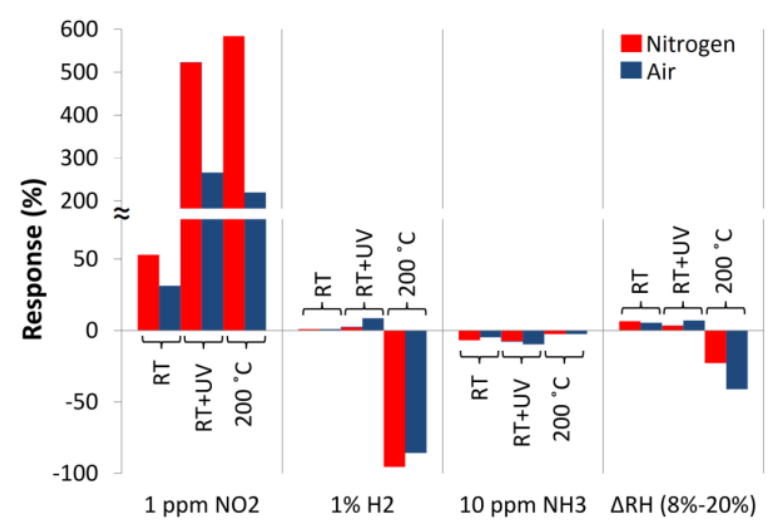

Figure 16. Comparison of the sensitivity of $\mathrm{ZnO}$ nanostructures to the action of selected gases.

The results confirmed a strong increase in the responses of $\mathrm{ZnO}$ nanostructures at $200{ }^{\circ} \mathrm{C}$. In dark conditions at RT the structure recovery was very weak or was not observed, whereas at $200{ }^{\circ} \mathrm{C}$ effective recovery occurred. The UV excitation of the $\mathrm{ZnO}$ nanostructures enabled effective recovery of the structure after its reaction with $\mathrm{NO}_{2}$ already at RT. Under UV condition at RT structure responses to $\mathrm{NO}_{2}$ are comparable with responses at $200^{\circ} \mathrm{C}$. The studies showed a limited impact of $\mathrm{RH}$ on the electrical resistance of $\mathrm{ZnO}$ nanostructures. At $\mathrm{RT}$ the impact of $\mathrm{RH}$ to the structure resistance is weaker than at elevated temperature. Also the different sorption mechanisms of the interaction of water molecules with $\mathrm{ZnO}$ nanostructures at $\mathrm{RT}$ and a temperature of $200{ }^{\circ} \mathrm{C}$ were observed (different directions of the reactions).

The interactions of $\mathrm{ZnO}$ nanostructures with gases showed typical reactions: their electrical conductivity increases when exposed to reducing gases $\left(\mathrm{H}_{2}\right.$ and $\left.\mathrm{NH}_{3}\right)$, and decreases during exposure to oxidizing gases $\left(\mathrm{O}_{2}\right.$ and $\left.\mathrm{NO}_{2}\right)$. Generally, at $\mathrm{RT}$, the gas molecules interact with $\mathrm{ZnO}$ nanostructures primarily physically (except $\mathrm{NO}_{2}$ ), while at elevated temperatures, these interactions have the character of chemical adsorption [31]. It has to be stressed that the $\mathrm{ZnO}$ nanostructures are particularly sensitive to the presence of $\mathrm{NO}_{2}$ under both atmospheres (air and nitrogen). The response (Equation (1)) of $\mathrm{ZnO}$ nanostructure to the effect of $\mathrm{NO}_{2}$ at a temperature of $200{ }^{\circ} \mathrm{C}$ is more than $10^{5}$ times greater than the response of $\mathrm{NH}_{3}$, and more than $10^{6}$ times greater than that to $\mathrm{H}_{2}$ in the relation of $1 \mathrm{ppm}$. Thus the selectivity of the structure for $\mathrm{NO}_{2}$ is very good. What is more the selectivity to $\mathrm{NO}_{2}$ at $\mathrm{RT}$ with $\mathrm{UV}$ excitation increases in comparison to elevated temperature.

In Table 1 the comparison the response of the investigated structure to $1 \mathrm{ppm}$ of $\mathrm{NO}_{2}$ to other $\mathrm{ZnO}$ nanostructure based gas sensors responses is presented. This comparison shows that the response of the presented structure is higher or comparable to other approaches. What is more under UV radiation 
high response is observed also at RT. This shows the possibility of detection of small concentrations of $\mathrm{NO}_{2}$ at RT with good sensitivity comparable to high temperature sensors $\left(>20{ }^{\circ} \mathrm{C}\right)$. Operation of a potential sensor at RT ensures low energy consumption and improves the safety of its usage.

Table 1. Comparison of responses of $\mathrm{ZnO}$ nanostructure based $\mathrm{NO}_{2}$ sensors with investigated $\mathrm{ZnO}$ nanostructures.

\begin{tabular}{|c|c|c|c|c|c|}
\hline Material (Structure) & Synthesis Method & $\begin{array}{c}\mathrm{NO}_{2} \\
\text { Concentration }\end{array}$ & $\begin{array}{c}\text { Operating } \\
\text { Temperature }\end{array}$ & $\begin{array}{c}\text { Response } \\
\text { (Carrier Gas) }\end{array}$ & Reference \\
\hline $\begin{array}{c}\mathrm{ZnO} \text { (mixture of } \\
\text { nanotubes and } \\
\text { nanoparticles) }\end{array}$ & Hydrothermal & $1 \mathrm{ppm}$ & $200^{\circ} \mathrm{C}$ & $\begin{array}{c}600 \% \text { (in nitrogen) } \\
232 \% \text { (in air) }\end{array}$ & $\begin{array}{l}\text { Current } \\
\text { paper }\end{array}$ \\
\hline $\begin{array}{c}\mathrm{ZnO} \text { (mixture of } \\
\text { nanotubes and } \\
\text { nanoparticles) }\end{array}$ & Hydrothermal & $1 \mathrm{ppm}$ & $\begin{array}{l}\mathrm{RT}\left(23^{\circ} \mathrm{C}\right)+ \\
\text { UV excitation }\end{array}$ & $\begin{array}{c}431 \% \text { (in nitrogen) } \\
341 \% \text { (in air) }\end{array}$ & $\begin{array}{l}\text { Current } \\
\text { paper }\end{array}$ \\
\hline $\begin{array}{l}\mathrm{ZnO} \text { (nanoporous } \\
\text { thin film) }\end{array}$ & Sol-gel & 100 ppm & $200^{\circ} \mathrm{C}$ & $37 \%$ (in air) & [47] \\
\hline $\mathrm{ZnO}$ (nanoflowers) & Hydrothermal & 20 ppm & $200^{\circ} \mathrm{C}$ & $\begin{array}{l}9 \% \text { (in air) } 33 \% \\
\text { (in nitrogen) }\end{array}$ & [21] \\
\hline $\begin{array}{c}\mathrm{ZnO}+2 \% \mathrm{TiO}_{2} \\
\text { (nanocomposite) }\end{array}$ & Wet-chemical route & 20 ppm & $250^{\circ} \mathrm{C}$ & $58 \%(-)$ & [48] \\
\hline $\mathrm{ZnO}$ (F doped thin film) & $\begin{array}{l}\text { Chemical spraying } \\
\text { method }\end{array}$ & $1 \mathrm{ppm}$ & $200^{\circ} \mathrm{C}$ & $90 \%$ (in air) & [49] \\
\hline $\begin{array}{l}\mathrm{ZnO} \text { (nanoparticles on } \\
\text { sepiolite matix) }\end{array}$ & $\begin{array}{l}\text { Participation onto } \\
\text { sepiolite matrix }\end{array}$ & $2.5 \mathrm{ppm}$ & $300^{\circ} \mathrm{C}$ & $1.1\left(R_{a} / R_{g}\right.$ in air $)$ & [50] \\
\hline $\mathrm{ZnO}$ (nanorods) & $\begin{array}{l}\text { Plate method with } \\
\text { hydrothermal } \\
\text { deposition }\end{array}$ & 10 ppm & $200^{\circ} \mathrm{C}$ & $4\left(R_{a} / R_{g}\right.$ in air $)$ & [51] \\
\hline $\begin{array}{c}\mathrm{ZnO} \\
\text { (nanoneedles)/ZnO } \\
\text { (cacti-like structures) }\end{array}$ & $\begin{array}{l}\text { Chemical route on } \\
\text { glass substrate }\end{array}$ & 200 ppm & $200^{\circ} \mathrm{C}$ & $\begin{array}{l}64 \% \text { (in air) } / 89 \% \\
\text { (in air) }\end{array}$ & [52] \\
\hline $\mathrm{ZnO}$ (Nanotetrapods) & $\begin{array}{l}\text { Thermal evaporation } \\
\text { controlled oxidation }\end{array}$ & 20 ppm & $300^{\circ} \mathrm{C}$ & $2000 \%$ (in air) & [53] \\
\hline
\end{tabular}

In comparison to the flower-like $\mathrm{ZnO}$ nanostructures which were investigated as a gas sensing material in our earlier work [21] the structure presented in this paper has better sensing properties (smaller noise level and much higher sensitivity to gases). Thanks to the use of a mixture of small grains and nanowires layers with improved adhesion and electrical stability were obtained. This proves that morphology has a very high impact on material sensing properties which are improved by the nanoparticle content in the investigated nanostructures.

It may be expected that the $\mathrm{ZnO}$ nanostructures allow the detection of low concentrations of $\mathrm{NO}_{2}$ in the range of ppb even at RT (with UV excitation). The investigated $\mathrm{ZnO}$ nanoparticles presents a high selectivity to $\mathrm{NO}_{2}$ and could be practically used as a sensor for this gas (e.g., for environmental monitoring). Such a high sensitivity of the $\mathrm{ZnO}$ nanostructures exposed to $\mathrm{NO}_{2}$ provides an opportunity to apply this type of $\mathrm{ZnO}$ nanostructures to detect vapors of explosives in the environment [54].

Acknowledgments: The work was partially financed by the Polish National Science Centre (NCN) within the grant 2012/07/B/ST7/01 471 and Silesian University of Technology, Faculty of Electrical Engineering within grants BK/232/Re4/2016 and BKM/534/Re4/2015.

Author Contributions: Marcin Procek designed and carried out the experiments, designed the experiment stand, cooperated in technology processes, made material characterization, analyzed the data, and participated in preparing the paper; Tadeusz Pustelny elaborated a concept of studies, analyzed and discussed the data, and participated in preparing the paper; Agnieszka Stolarczyk designed and dealt with the technology process and described it in the text, partially analyzed the data and participated in preparing the paper.

Conflicts of Interest: The authors declare no conflict of interest. 


\section{References}

1. Li, L.; Zhai, T.; Bando, Y.; Golberg, D. Recent progress of one-dimensional ZnO nanostructured solar cells. Nano Energy 2012, 1, 91-106. [CrossRef]

2. Kayaci, F.; Vempati, S.; Donmez, I.; Biyikli, N.; Uyar, T. Role of zinc interstitials and oxygen vacancies of $\mathrm{ZnO}$ in photocatalysis: A bottom-up approach to control defect density. Nanoscale 2014, 6, 10224. [CrossRef] [PubMed]

3. Cun, T.; Dong, C.; Huang, Q. Ionothermal precipitation of highly dispersive ZnO nanoparticles with improved photocatalytic performance. Appl. Surf. Sci. 2016, 384, 73-82. [CrossRef]

4. Xu, L.; Zheng, G.; Wang, J.; Xian, F.; Liu, Y. Stable co-emission of UV, green and red light in ZnO thin films with rapid annealing treatment. Opt. Int. J. Light Electron Opt. 2016, 127, 5942-5949. [CrossRef]

5. Saoud, F.S.; Plenet, J.C.; Henini, M. Band gap and partial density of states for ZnO: Under high pressure. J. Alloys Compd. 2015, 619, 812-819. [CrossRef]

6. Ojha, A.K.; Srivastava, M.; Kumar, S.; Hassanein, R.; Singh, J.; Singh, M.K.; Materny, A. Influence of crystal size on the electron-phonon coupling in $\mathrm{ZnO}$ nanocrystals investigated by Raman spectroscopy. Vib. Spectrosc. 2014, 72, 90-96. [CrossRef]

7. Morkoc, H.; Ozgur, U. Zinc Oxide: Fundamentals, Materials and Device Technology; Wiley-VCH Verlag GmbH \& Co. KGaA: Weinheim, Germany, 2009.

8. Chen, M.; Wang, Z.; Han, D.; Gu, F.; Guo, G. High-sensitivity $\mathrm{NO}_{2}$ gas sensors based on flower-like and tube-like ZnO nanomaterials. Sens. Actuators B 2011, 157, 565-574. [CrossRef]

9. Klingshirn, C. ZnO: Material, physics and applications. ChemPhysChem 2007, 8, 782-803. [CrossRef] [PubMed]

10. Yuan, W.; Liu, A.; Huang, L.; Li, C.; Shi, G. High-performance $\mathrm{NO}_{2}$ sensors based on chemically modified graphene. Adv. Mater. 2013, 25, 766-771. [CrossRef] [PubMed]

11. Fanni, L.; Aebersold, B.A.; Alexander, D.T.L.; Ding, L.; Morales Masis, M.; Nicolay, S.; Ballif, C. c-texture versus $a$-texture low pressure metalorganic chemical vapor deposition $\mathrm{ZnO}$ films: Lower resistivity despite smaller grain size. Thin Solid Films 2014, 565, 1-6. [CrossRef]

12. Rai, P.; Khan, R.; Ahmad, R.; Hahn, Y.-B.; Lee, I.-H.; Yu, Y.-T. Gas sensing properties of single crystalline ZnO nanowires grown by thermal evaporation technique. Curr. Appl. Phys. 2013, 13, 1769-1773. [CrossRef]

13. Tian, Y.; Li, J.; Xiong, H.; Dai, J. Controlled synthesis of ZnO hollow microspheres via precursor-template method and its gas sensing property. Appl. Surf. Sci. 2012, 258, 8431-8438. [CrossRef]

14. Bai, S.; Sun, C.; Guo, T.; Luo, R.; Lin, Y.; Chen, A.; Sun, L.; Zhang, J. Low temperature electrochemical deposition of nanoporous $\mathrm{ZnO}$ thin films as novel $\mathrm{NO}_{2}$ sensors. Electrochim. Acta 2013, 90, 530-534. [CrossRef]

15. Thareja, R.K.; Saxena, H.; Narayanan, V. Laser-ablated $\mathrm{ZnO}$ for thin films of $\mathrm{ZnO}$ and $\mathrm{Mg}_{x} \mathrm{Zn}_{(1-x)} \mathrm{O}$. J. Appl. Phys. 2005, 98, 34908. [CrossRef]

16. Kołodziejczak-Radzimska, A.; Jesionowski, T.; Krysztafkiewicz, A. Obtaining zinc oxide from aqueous solutions of $\mathrm{KOH}$ and $\mathrm{Zn}\left(\mathrm{CH}_{3} \mathrm{COO}\right)_{2}$. Physicochem. Probl. Miner. Process. 2010, 44, 93-102.

17. Tong, Y.; Liu, Y.; Dong, L.; Zhao, D.; Zhang, J.; Lu, Y.; Shen, D.; Fan, X. Growth of ZnO nanostructures with different morphologies by using hydrothermal technique. J. Phys. Chem. B 2006, 110, 20263-20267. [CrossRef] [PubMed]

18. Neri, G. First fifty years of chemoresistive gas sensors. Chemosensors 2015, 3, 1-20. [CrossRef]

19. Pustelny, T.; Procek, M.; Maciak, E.; Stolarczyk, A.; Drewniak, S.; Urbańczyk, M.; Setkiewicz, M.; Gut, K.; Opilski, Z. Gas sensors based on nanostructures of semiconductors $\mathrm{ZnO}$ and $\mathrm{TiO}_{2}$. Bull. Pol. Acad. Sci. Tech. Sci. 2012, 60, 853-859. [CrossRef]

20. Djurišić, A.B.; Chen, X.; Leung, Y.H.; Man Ching Ng, A. ZnO nanostructures: Growth, properties and applications. J. Mater. Chem. 2012, 22, 6526. [CrossRef]

21. Procek, M.; Pustelny, T.; Stolarczyk, A.; Maciak, E. Studies of changes in electrical resistance of zinc oxide nanostructures under the influence of variable gaseous environments. Bull. Pol. Acad. Sci. Tech. Sci. 2014, 62, 635-639. [CrossRef]

22. Wang, Y.; Ma, C.; Sun, X.; Li, H. Preparation of nanocrystalline metal oxide powders with the surfactant-mediated method. Inorg. Chem. Commun. 2002, 5, 751-755. [CrossRef] 
23. Li, P.; Wei, Y.; Liu, H.; Wang, X. Growth of well-defined $\mathrm{ZnO}$ microparticles with additives from aqueous solution. J. Solid State Chem. 2005, 178, 855-860. [CrossRef]

24. Djurišić, A.B.; Chen, X.Y.; Leung, Y.H. Recent progress in hydrothermal synthesis of zinc oxide nanomaterials. Recent Pat. Nanotechnol. 2012, 6, 124-134. [CrossRef] [PubMed]

25. Zhao, X.; Li, M.; Lou, X. Sol-gel assisted hydrothermal synthesis of ZnO microstructures: Morphology control and photocatalytic activity. Adv. Powder Technol. 2014, 25, 372-378. [CrossRef]

26. Liu, X.; Cheng, S.; Liu, H.; Hu, S.; Zhang, D.; Ning, H. A survey on gas sensing technology. Sensors 2012, 12, 9635-9665. [CrossRef] [PubMed]

27. Kumar, R.; Al-Dossary, O.; Kumar, G.; Umar, A. Zinc oxide nanostructures for $\mathrm{NO}_{2}$ gas-sensor applications: A review. Nano Micro Lett. 2015, 7, 97-120. [CrossRef]

28. Fine, G.F.; Cavanagh, L.M.; Afonja, A.; Binions, R. Metal oxide semi-conductor gas sensors in environmental monitoring. Sensors 2010, 10, 5469-5502. [CrossRef] [PubMed]

29. Abdullah, N.A.; Khusaimi, Z.; Mohammad Rusop, M. A review on zinc oxide nanostructures: Doping and gas sensing. Adv. Mater. Res. 2013, 667, 329-332. [CrossRef]

30. Procek, M.; Pustelny, T. A study of gas sensing properties of ZnO nanostructures activated by UV light. Photonics Lett. Pol. 2015, 7, 50-52.

31. Barsan, N.; Weimar, U. Conduction model of metal oxide gas sensors. J. Electroceram. 2001, 7, $143-167$. [CrossRef]

32. An, W.; $\mathrm{Wu}, \mathrm{X}$; Zeng, X.C. Adsorption of $\mathrm{O}_{2}, \mathrm{H}_{2}, \mathrm{CO}, \mathrm{NH}_{3}$ and $\mathrm{NO}_{2}$ on $\mathrm{ZnO}$ nanotube: A density functional theory study. J. Phys. Chem. C 2008, 112, 5747-5755. [CrossRef]

33. Struk, P.; Pustelny, T.; Gołaszewska, K.; Borysiewicz, M.A.; Piotrowska, A. Gas sensors based on ZnO structures. Acta Phys. Pol. A 2013, 124, 567-569. [CrossRef]

34. Gaman, V.I. Physical principles of operation of oxidizing gas sensors based on metal oxide semiconductors. Russ. Phys. J. 2012, 54, 1364-1371. [CrossRef]

35. Ristić, M.; Musić, S.; Ivanda, M.; Popović, S. Sol-gel synthesis and characterization of nanocrystalline ZnO powders. J. Alloys Compd. 2005, 397, L1-L4. [CrossRef]

36. Chen, X.; Wong, C.K.Y.; Yuan, C.A.; Zhang, G. Nanowire-based gas sensors. Sens. Actuators B 2013, 177, 178-195. [CrossRef]

37. Yamazoe, N.; Shimanoe, K. Theory of power laws for semiconductor gas sensors. Sens. Actuators B 2008, 128, 566-573. [CrossRef]

38. Gao, X.; Li, X.; Yu, W. Synthesis and characterization of flowerlike $\mathrm{ZnO}$ nanostructures via an ethylenediamine-meditated solution route. J. Solid State Chem. 2005, 178, 1139-1144. [CrossRef]

39. Pustelny, T.; Setkiewicz, M.; Drewniak, S.; MacIak, E.; Stolarczyk, A.; Urbańczyk, M.; Procek, M.; Gut, K.; Opilski, Z.; Pasternak, I.; et al. The sensibility of resistance sensor structures with graphene to the action of selected gaseous media. Bull. Pol. Acad. Sci. Tech. Sci. 2013, 61, 293-300.

40. Zhao, J.; Yang, T.; Liu, Y.; Wang, Z.; Li, X.; Sun, Y.; Du, Y.; Li, Y.; Lu, G. Enhancement of $\mathrm{NO}_{2}$ gas sensing response based on ordered mesoporous Fe-doped $\mathrm{In}_{2} \mathrm{O}_{3}$. Sens. Actuators B 2014, 191, 806-812. [CrossRef]

41. Mishra, S.; Ghanshyam, C.; Ram, N.; Bajpai, R.P.; Bedi, R.K. Detection mechanism of metal oxide gas sensor under UV radiation. Sens. Actuators B 2004, 97, 387-390. [CrossRef]

42. Yamazoe, N.; Suematsu, K.; Shimanoe, K. Extension of receptor function theory to include two types of adsorbed oxygen for oxide semiconductor gas sensors. Sens. Actuators B 2012, 163, 128-135. [CrossRef]

43. Procek, M.; Pustelny, T. Analysis of the responses of metal-Oxide semiconductor nanostructures to nitrogen dioxide. Acta Phys. Pol. A 2013, 124, 529-533. [CrossRef]

44. Mikhaylov, R.V.; Lisachenko, A.A.; Shelimov, B.N.; Kazansky, V.B.; Martra, G.; Coluccia, S. FTIR and TPD study of the room temperature interaction of a $\mathrm{NO}-$ Oxygen mixture and of $\mathrm{NO}_{2}$ with titanium dioxide. J. Phys. Chem. C 2013, 117, 10345-10352. [CrossRef]

45. Chen, H.; Liu, Y.; Xie, C.; Wu, J.; Zeng, D.; Liao, Y. A comparative study on UV light activated porous $\mathrm{TiO}_{2}$ and $\mathrm{ZnO}$ film sensors for gas sensing at room temperature. Ceram. Int. 2012, 38, 503-509. [CrossRef]

46. Meyer, B. First-principles study of the polar O-terminated $\mathrm{ZnO}$ surface in thermodynamic equilibrium with oxygen and hydrogen. Phys. Rev. B 2003, 69, 45416. [CrossRef]

47. Chougule, M.A.; Sen, S.; Patil, V.B. Fabrication of nanostructured $\mathrm{ZnO}$ thin film sensor for $\mathrm{NO}_{2}$ monitoring. Ceram. Int. 2012, 38, 2685-2692. [CrossRef] 
48. Vyas, R.; Sharma, S.; Gupta, P.; Vijay, Y.K.; Prasad, A.K.; Tyagi, A.K.; Sachdev, K.; Sharma, S.K. Enhanced $\mathrm{NO}_{2}$ sensing using $\mathrm{ZnO}-\mathrm{TiO}_{2}$ nanocomposite thin films. J. Alloys Compd. 2013, 554, 59-63. [CrossRef]

49. Şennik, E.; Kerli, S.; Alver, Ü.; Öztürk, Z.Z. Effect of fluorine doping on the $\mathrm{NO}_{2}$-sensing properties of $\mathrm{ZnO}$ thin films. Sens. Actuators B 2015, 216, 49-56. [CrossRef]

50. Hassan, M.; Afify, A.S.; Tulliani, J.M. Synthesis of ZnO nanoparticles onto sepiolite needles and determination of their sensitivity toward humidity, $\mathrm{NO}_{2}$ and $\mathrm{H}_{2}$. J. Mater. Sci. Technol. 2016, 32, 573-582. [CrossRef]

51. Harale, N.S.; Kamble, A.S.; Tarwal, N.L.; Mulla, I.S.; Rao, V.K.; Kim, J.H.; Patil, P.S. Hydrothermally grown $\mathrm{ZnO}$ nanorods arrays for selective $\mathrm{NO}_{2}$ gas sensing: Effect of anion generating agents. Ceram. Int. 2016, 42, 12807-12814. [CrossRef]

52. Pawar, R.C.; Lee, J.W.; Patil, V.B.; Lee, C.S. Synthesis of multi-dimensional ZnO nanostructures in aqueous medium for the application of gas sensor. Sens. Actuators B 2013, 187, 323-330. [CrossRef]

53. Calestani, D.; Zha, M.; Mosca, R.; Zappettini, A.; Carotta, M.C.; Di Natale, V.; Zanotti, L. Growth of ZnO tetrapods for nanostructure-based gas sensors. Sens. Actuators B 2010, 144, 472-478. [CrossRef]

54. Procek, M.; Stolarczyk, A.; Pustelny, T.; Maciak, E. A study of a QCM sensor based on $\mathrm{TiO}_{2}$ nanostructures for the detection of $\mathrm{NO}_{2}$ and explosives vapours in air. Sensors 2015, 15, 9563-9581. [CrossRef] [PubMed]

(C) 2016 by the authors; licensee MDPI, Basel, Switzerland. This article is an open access article distributed under the terms and conditions of the Creative Commons Attribution (CC-BY) license (http://creativecommons.org/licenses/by/4.0/). 